\title{
SERVICE LEVEL AGREEMENT DIRECTED TO SUPPLIERS OF MATERIALS AND SERVICES OF THE PETROCHEMICAL SECTOR: A CRITERIA ANALYSIS
}

\author{
(D) Karla Moreira Finn ${ }^{1}$ (Dabiano de Lima Nunes ${ }^{2}$ (Dristine Hermann Nodari ${ }^{3}$ Jefferson Dobner Sordi ${ }^{4}$ \\ ${ }^{I}$ Especialista, Feevale University - FEEVALE. Novo Hamburgo, Rio Grande do Sul-Brazil. karlafinn1007@gmail.com \\ ${ }^{2}$ Mestre, Feevale University - FEEVALE. Novo Hamburgo, Rio Grande do Sul-Brazil. fabianonunes@feevale.br \\ ${ }^{3}$ Doutor, Feevale University - FEEVALE. Porto Alegre, Rio Grande do Sul - Brazil. cristine.nodari@ gmail.com \\ ${ }^{4}$ Doutor, Feevale University-FEEVALE. Novo Hamburgo, Rio Grande do Sul-Brazil. jefferson@feevale.br
}

\begin{abstract}
Objective: This research aims at suggesting a conceptual model for the formulation of service level agreement, directed at suppliers of materials and services of the petrochemical sector.

Methodology: This is a descriptive research whose analysis method was done through structural equation modelling, and the data came from a survey with 104 collaborators in the supply chain of the petrochemical sector in the state of Rio Grande do Sul, Brazil.

Originality: Upon considering the reality of the Southern Petrochemical Centre, it is possible to understand this research's findings to the elaboration of service levels according to competitive criteria that become fundamental for the management process and competitiveness strategy in the search for suppliers by selecting the criteria that must be analysed upon establishing a new partner.

Main results: All constructs suggested in this research had a 73\% impact on the supply chain management construct with a service level agreement. The delivery, quality and service level construct presented the highest load obtained, followed by the quality and flexibility construct and finally the cost construct.

Theoretical contributions: The supply chains play an important role in the accomplishment of the company's objectives. Its mission is to notice the competitive needs of products and services by becoming responsible for the delivery at the right time, costs, quality and other elements in the operations' strategy. According to the suggested model, all structures that encompass the competitive criteria positively impacted the supply chain management and the service level agreement, expanding the academic debate in the development of competitive advantage.
\end{abstract}

Keywords: Service level agreement. Structural equation modelling. Supply Chain Management. Competitive criteria.

\section{ACORDO DE NÍVEIS DE SERVIÇO DIRECIONADOS AOS FORNECEDORES DE MATERIAIS E SERVICOS NO SETOR PETROQUÍMICO: ANÁLISE DE CRITÉRIOS}

\section{Resumo}

Objetivo: A pesquisa tem como objetivo sugerir um modelo conceitual para a formulação de acordos de nível de serviço, direcionado a fornecedores de materiais e serviços do setor petroquímico.

Metodologia: Trata-se de uma pesquisa descritiva cujo método de análise foi feito por meio de modelagem de equações estruturais, e os dados foram provenientes de uma survey com 104 colaboradores da cadeia de suprimentos do setor petroquímico no estado do Rio Grande do Sul, Brasil.

Originalidade: Ao considerar a realidade do Pólo Petroquímico do Sul, é possível compreender os achados desta pesquisa para a elaboração de níveis de serviço segundo critérios competitivos que se tornam fundamentais para o processo de gestão e estratégia de competitividade na busca de fornecedores por meio da seleção dos critérios que deve ser analisado ao estabelecer um novo parceiro.

Principais resultados: Todos os construtos, sugeridos nesta pesquisa, tiveram um impacto de $73 \%$ no construto de gestão da cadeia de suprimentos com um acordo de nível de serviço. O construto entrega, qualidade e nível de serviço apresentou a maior carga obtida, seguido pelo construto qualidade e flexibilidade e por último o construto custo.
Contribuições teóricas: As cadeias de abastecimento desempenham um papel importante na realização dos objetivos da empresa. Sua missão é perceber as necessidades competitivas de produtos e serviços, tornando-se responsável pela entrega no tempo certo, custos, qualidade e outros elementos da estratégia de operações. De acordo com o modelo sugerido, todas as estruturas que englobam os critérios competitivos impactaram positivamente a gestão da cadeia de suprimentos e o acordo de nível de serviço ampliando o debate acadêmico no desenvolvimento de vantagem competitiva.

Palavras-chave: Acordo de nível de serviço. Modelagem de equações estruturais. Gestão da cadeia de abastecimento. Critérios competitivos.

\section{ACUERDO DE NIVEL DE SERVICIO DIRIGIDO A PROVEEDORES DE MATERIALES Y SERVICIOS EN EL SECTOR PETROQUÍMICO: ANÁLISIS DE CRITERIOS}

\begin{abstract}
Resumen
Objetivo: Esta investigación tiene como objetivo sugerir un modelo conceptual para la formulación de acuerdo de nivel de servicio, dirigido a proveedores de materiales y servicios del sector petroquímico.

Metodología: Se trata de una investigación descriptiva cuyo método de análisis se realizó mediante el modelado de ecuaciones estructurales, y los datos provienen de una encuesta a 104 colaboradores de la cadena de suministro del sector petroquímico en el estado de Rio Grande do Sul, Brasil. Originalidad: Al considerar la realidad del Centro Petroquímico Sur, es posible comprender los hallazgos de esta investigación para la elaboración de niveles de servicio de acuerdo a criterios competitivos que se tornan fundamentales para el proceso de gestión y estrategia de competitividad en la búsqueda de proveedores mediante la selección de los criterios que debe analizarse al establecer un nuevo socio.

Resultados principales: Todos los constructos sugeridos en esta investigación tuvieron un impacto del $73 \%$ en el constructo de gestión de la cadena de suministro con un acuerdo de nivel de servicio. La construcción de entrega, calidad y nivel de servicio presentó la carga más alta obtenida, seguida por la construcción de calidad y flexibilidad y finalmente la construcción de costos.

Contribuciones teóricas: Las cadenas de suministro juegan un papel importante en el logro de los objetivos de la empresa. Su misión es advertir las necesidades competitivas de productos y servicios haciéndose responsable de la entrega en el momento adecuado, los costos, la calidad y otros elementos de la estrategia de operaciones. De acuerdo con el modelo sugerido, todas las estructuras que engloban los criterios competitivos impactaron positivamente la gestión de la cadena de suministro y el acuerdo de nivel de servicio, ampliando el debate académico en el desarrollo de la ventaja competitiva.
\end{abstract}

Palabras clave: Acuerdo de nivel de servicio. Modelado de ecuaciones estructurales. Gestión de la cadena de suministro. Criterios competitivos.

Cite as / Como citar

American Psychological Association (APA)

Finn, K. M., Nunes, F. de L., Nodari, C. H., \& Sordi, J. D. (2020, Oct./Dec.). Service level agreement directed to suppliers of materials and services of the petrochemical sector: a criteria analysis. Iberoamerican Journal of Strategic Management (IJSM), 19(4), 151-171. https://doi.org/10.5585/riae.v19i4.16847.

FINN, K. M.; NUNES, F. de L.; NODARI, C. H.; SORDI, J. D. Service level agreement directed to suppliers of materials and services of the petrochemical sector: a criteria analysis. Iberoamerican Journal of Strategic Management (IJSM), v. 19, n. 4, p. 151-171, Oct./Dec. 2020

https://doi.org/10.5585/riae.v19i4.16847. 


\section{Introduction}

In the endless search to be in the market, which is configured as competitive, the organisations aim at establishing strategies with the objective to reach differentiation and a prominent position, besides recognition in the area where they operate. For this purpose, in order for every productive chain to be developed satisfactorily, the suppliers must be chosen criteriously. To this end, such measures must be established for the creation and determination of service levels that are wanted and expected by the company (Teixeira et al., 2014).

Within the organisation, the supply chain management (SCM) aims at creating value, and its most distinguished relevance stands out to the clients and suppliers that are inserted in this administration. This process manifests primarily in terms of time and place. Products and services have no value unless they are in the hands of the clients when and where they wish. A good management administration of all the supply chain interprets each activity as a contributor to this process of adding value (Ballou, 2007).

In several segments, clients usually use service level agreement (SLA) to outline performance expectations from their suppliers and determine the penalties in case the rules and requirements are not strictly met. Chen and Thomas (2017) emphasise that the SLA application can be efficient in the coordination and management of the supply chain, since these criteria will measure service quality as a whole. SLA assures the measurement of the services delivered by transforming these criteria into performance indexes for the suppliers' assessment (Muller et al., 2017).

Thus, this article aims at answering the following research question: What are the criteria to establish SLA of goods and services supply perceived by professionals from the supply area in the petrochemical sector? Therefore, the general objective was to suggest a model for the preparation of SLA directed to suppliers of goods and services in the petrochemical sector in Southern Brazil. This is a descriptive research where the analysis method happened through structural equation modelling and the data came from a survey with 104 collaborators from the supply area in the petrochemical sector from the state of Rio Grande do Sul, Brazil.

This research's relevance is supported by two dimensions. The first dimension is scientific for the area of management, economics and production. From a theoretical framework survey in the SCOPUS database (limited to the time period between 1967 and 2017), it was possible to see that, by informing the key words related to this work's subject (SLA/ SCM and structural equation modelling), the result was not achieved. For the search on SLA and SCM, the result was 50 documents, of which eight publications consisted of SLA for the management of offer, stock projection management, and product delivery time reduction, among others, with the use of robust statistical techniques (Bogataj et al., 2016; Eltantawy et al., 2015). It is worth mentioning that, working on and implementing SLA without adopting a method to measure and parametrise information brings low reliability into this strategy. Consequently, through statistical procedures, it is possible to assess the relationship between the analysed variables by solidifying the accomplishment of a quantitative study on the theoretical models hypothesised by researchers (Hair Jr. 
et al., 2010). In this sense, this research aims to contribute to this gap, that is, to present, discuss and measure the action of the competitive criteria in service levels conditioned to supply chain management to promote the generation of value as a strategic differential (Bogataj et al., 2016).

The second dimension that is relevant to this research is the regional development's economic representativeness in the Brazilian context. The Southern Petrochemical Centre (Rio Grande do Sul, Brazil) contributes to the creation of jobs and income, the formation and exploration of new businesses, the launch of innovative products, and the development of local companies (Eidelwein et al., 2016; Krummenauer \& Nunes, 2017). In the Brazilian context, the petrochemical industry had a net income of US\$10,8 billion in 2018 (BCIA, 2018). Therefore, upon suggesting a model of SLA elaboration, one can contribute to the development of competitiveness in this distinctive sector of economy in the country.

\section{Background}

The SCM is a set of companies that collaborate to the boost of the strategic positioning and the improvement of the operational efficiency. To each company involved, the SCM reflects on the strategic choice. The supply chain operations demand managerial processes that cover functional areas within individual organisations and link commercial partners and clients through the organisations' limits (Bowersox et al., 2002).

A supply chain encompasses all the steps involved, both directly and indirectly, when a client places an order, and it is not include only manufacturers and suppliers, but also carriers, warehouses, retail stores and the clients themselves, with the maximisation of the general added value as its main objective (Chopra $\&$ Meindl, 2016). SCM is the integration of the main end user's business processes through suppliers of goods and services and information that add value to the clients and to other interested parties (Lambert et al., 1998; Vitorino Filho \& Moori, 2018).

In order to stay competitive in the market where they operate, the organisations need to develop strategies to trace their differentiation and prominence in this market. Thus, a set of consistent criteria is determined in to reach efficiency and preference along with their clients. The elements that make up the competitive strategy that are the foundation for taking decisions consist of: cost and differentiation, with the latter one composed by four pillars, which are delivery quality, flexibility, innovation and performance (Boyer, 1998; Lau Antonio et al., 2007; Menor et al., 2001; Neto et al., 2003; Rosenzweig \& Roth, 2004; Sellitto et al., 2015; Teece, 2010). Table 1 aims at presenting the concepts synthetically by relating them to the clients' expectations and to the production strategies, with the objective to present the generic factors that the clients recognise and value, thus facilitating the identification of the strategies to be used by the production staff, so that the clients' objectives may be reached. 
Table 1 - Relationship of the clients' objectives with the production competitive criteria
Clients' Objective
Production Competitive Criteria

\section{PRICE}

Lower price

Payment condition

DELIVERY

Delivery time

Guarantee of on-time delivery

PRODUCT

Product performance

Possibility of changes

Insertion of new products

\section{COST}

Lower cost (productivity increase)

Cash flow adequacy

DELIVERY PERFORMANCE

Production Speed

Delivery reliability

QUALITY

Project-compliance

Process quality (adequate execution)

FLEXIBILITY

Delivery flexibility

Production flexpibility

INNOVATION

Source: Adapted from Menor (2001). Rosenzweig \& Roth (2004), Lau Antonio et al. (2007) and Sellitto et al. (2015).

In the supply chain pattern, the service levels are present in the expectation communication concerning the stock levels, in the relationship between clients and suppliers and in the product and market segmentation due to its relevance or profitability. One of the main service levels used as a performance index by the organisations is product availability. However, this availability parameter may appear under different models of mediation in different chain companies (Volk et al., 2009; Junior et al., 2014).

The index named product out of stock shows the probabilities of a breakdown during re-supply, no matter its magnitude. It is illustrated by stating that $85 \%$ of probability of an out-of-stock product shows that, on average, for every 100 re-supplies, 15 of them will be out of stock, no matter how many, one unit of a thousand of them, this parameter won't change (Zammori et al., 2009). Decrease the number of goods out of stock, some levels of service agreements between companies and their suppliers include penalties in case the supply conditions are not observed, no matter its nature (Singh et al., 2015).

SLAs are agreements between a service provider or a goods supplier and a client with the objective to define the obligations of the parties involved. SLA also specifies the measures to be taken in case there is non-compliance with service guarantees of goods supply, which were established between the parties (Ludwig et al., 2002).

The elements which characterise SLA are, by definition, performance levels in the services delivered and penalties applicable in cases which involve the deterioration of these levels. In order for the contractual mechanics to work well, it is extremely important that the service levels adjusted by the parties are objectively defined in a clear and precise way, and also supported by reasonable metrics that simultaneously guarantee quality for the contractor, which must be tangible by the service provider or goods supplier (Abbasi et al., 2018). The use of SLA prevailed in the organisations to describe the rights and duties of the parties involved in the provision of services or in the supply of goods, thus guaranteeing that all requirements are met. These requirements are measured through performance indexes, which, depending 
on the performance, may determine penalties or rewards to the supplier hired. In the face of this context, there were important evolutions directed to the SLA analysis automation (Muller et al., 2017).

In several sectors, the use of SLA is very common to describe the suppliers' performance expectations and specify the consequences of not following these rules. Such agreement may serve to encourage a supplier to improve the service delivered or the supply of the goods acquired without penalties or even additional benefits (Chen \& Thomas, 2017).

The service levels' monitoring and performance must be analysed and reported. The reference points and the metrics used must be specified in the agreement, which should be periodically revised and/or updated between the parties involved (Owoloko et al., 2017). It is essential to define, in this client's paperwork, that they are also responsible for supporting the service delivery process. SLA defines the "relationship", which is naturally and usually a mutual exchange of information. The client must provide the accesses, facilities and resources so that the supplying company’s employees may work there (Ludwig et al., 2002).

Generally speaking, the academic literature emphasises some steps in the service level agreement, which are: Parties - it describes the parties involved in service management or goods supply, the signatory parties and the support parties, which act on behalf of the service or goods provider. Service or supply definitions - it describes the services or goods supply where SLA will be applied and represent the mutual understanding between the parties in terms of service operations, parameters and metrics or goods supply, by determining measurement specifications as well. Duties - it defines the service level which will be ensured between suppliers and clients (Ludwig et al., 2002).

Studies show that, besides increasing the supplier's performance, an efficient SLA inserted in the supply chain will also improve the Pareto Chart, which enables the visualisation and identification of the main causes or problems, by allowing the concentration of efforts over them. SLA is very common in practise for the suppliers who manage goods in a wide variety of industries. Several articles show that the SLA non-compliance costs directly affect the suppliers' profitability (Chen \& Thomas, 2017).

\section{Method}

For classification purposes, this research aims at creating an understanding about the criteria that are relevant to the establishment of SLA service levels concerning the supply of materials and services that doesn't use a measurement model of this information. This is a descriptive research with a quantitative approach (Wheeldon \& Faubert, 2009). Concerning this research's procedure, the method used was a survey along with a structural equation modelling through Partial Least Squares (PLS) (Hair Jr. et al., 2010; Hair Jr et al., 2016; Voorhees et al., 2016; Wong, 2013).

The application of a Survey, which is conceptualised as the acquisition of data or information about the characteristics, actions or opinions of a certain group of people, referred to as public audience, through a research tool (Forza, 2002). The structural equation modelling (SEM) was used based on the following 
steps: 1) development of a theoretical model, 2) creation of a casual relation path diagram, 3) conversion of the previous step diagram, 4) choice of the matrix type of input data according to the model suggested, 5) assessment of the structural model, 6) assessment of the model and adjustment quality essays, 7) model analysis and amendment for attaining the final model (Hair Jr et al., 2014).

The questionnaire was designed and directed to buyers and professionals who work in the SCM area in the petrochemical sector from the state of Rio Grande do Sul (Brazil) and which holds all the knowledge about the flow of an operation with full autonomy to identify, based on the competitive criteria, which items must serve as basis for the measurement of the services or supply assessment of goods from their partners. The statements that came before the end questions in this research were personal with the objective to know the target audience and their domain over the topic addressed. There were five questions concerning age, gender, schooling, professional period of experience and position occupied. The questions were formatted according to the five-point Likert Scale based on the following classification: 1 - fully disagree, 2 - disagree, 3 - neither agree nor disagree, 4 - agree and 5 - fully agree (Sellitto et al., 2018).

The interviewees' profile, as well as their representativeness in the answers obtained, is shown in Table 2:

Table 2 - Interviewees' profile of the professionals from the industrial area

\begin{tabular}{lcc}
\hline \multicolumn{1}{c}{ Positions Interviewed } & No. of answers & $\begin{array}{c}\text { Representativeness in the } \\
\text { interviews' total (\%) }\end{array}$ \\
\hline Procurement Manager & 35 & 33,65 \\
Purchasing Coordinator & 24 & 23,08 \\
Buyer & 15 & 14,42 \\
Shopping Analyst & 13 & 12,5 \\
Shopping Supervisor & 7 & 6,73 \\
Purchasing Manager & 5 & 4,81 \\
Purchase Planning Analyst & 1 & 0,96 \\
Material Planning Analyst & 1 & 0,96 \\
Quality Analyst & 1 & 0,96 \\
Auxiliary II & 1 & 0,96 \\
Purchasing Engineer & 1 & 0,96 \\
\hline Total & $\mathbf{1 0 4}$ & $\mathbf{1 0 0}$
\end{tabular}

A pre-test was performed between July $20^{\text {th }}, 2018$, and August 3rd, 2018, with a sample of 13 respondents. The pre-test respondents presented a profile that was suitable for the research, that is, buyers and professionals from the SCM area who act directly with suppliers. The Cronbach's Alpha was calculated at 0,824 for a total of 30 questions (Malhotra, 2008) to attest the reliability in this pre-test. The petrochemical sector employs 6,300 people in your companies. The questionnaire was sent to 292 people, by accessibility and convenience. This people works in the areas of purchase, acquisition and supplies of sector's companies, between August $6^{\text {th }}$ and $24^{\text {th }}, 2018$. The questionnaires are sent to these professionals, and not to the entire universe of employees in the sector, due to the possibility of their contribution to achieve the research objective of this article. Among these, 104 answered the questionnaire and a return 
rate of $35,62 \%$ was obtained. According to literature, the mean return rate varies between $25 \%$ and $46 \%$ (Sheehan, 2006).

The variables which define each construct were specified to define the measurement model that will serve as restrictors of the criteria to be determined upon elaborating the model suggested in this research. The indexes are determined as the items answered in the questionnaire, which were determined as the variables analysed, with the constructs latent in relation to the factors (Hair Jr et al., 2014). At this stage, the research hypotheses were defined and they are related to the gaps that can be investigated and to the constructs. Table 3 shows the indexes and their description, linked to the research hypotheses, and the authors related to each topic.

Table 3 - Research constructs and hypotheses

\begin{tabular}{|c|c|c|c|}
\hline Variables analysed & Constructs & Hypotheses & Authors \\
\hline $\begin{array}{l}\text { CT1) The importance to seek suppliers who } \\
\text { long to have their production costs positively } \\
\text { impacted in all the supply chain. } \\
\text { CT2) The importance to seek suppliers who are } \\
\text { constantly concerned about reaching low } \\
\text { production costs and become flexible in the } \\
\text { need to adjust prices. } \\
\text { CT3) The importance to seek suppliers who } \\
\text { focus on productivity efficiency. } \\
\text { CT4) The importance to seek suppliers whose } \\
\text { practise is cost emphasis. } \\
\text { CT5) The importance to seek suppliers who } \\
\text { focus on improving their processes. }\end{array}$ & Costs & $\begin{array}{l}\text { H1: The competitive } \\
\text { strategy of costs } \\
\text { positively influences } \\
\text { the SCM with SLA }\end{array}$ & $\begin{array}{l}\text { (Porter, 2008; Ritson } \\
\text { et al., 2017; Sellitto } \\
\text { et al., 2018, 2015; } \\
\text { Slack et al., 2010; } \\
\text { Wang et al., 2016) }\end{array}$ \\
\hline $\begin{array}{l}\text { DE1) The importance to seek suppliers who } \\
\text { are committed to their delivery time. } \\
\text { DE2) The importance to seek suppliers who } \\
\text { are flexible in delivery, quantities, scheduled } \\
\text { delivery, partial delivery and product } \\
\text { alteration. } \\
\text { DE3) The importance to develop partnerships } \\
\text { with suppliers that respect delivery times as } \\
\text { well as the quantity agreed on. }\end{array}$ & $\begin{array}{c}\text { Delivery } \\
\text { performance }\end{array}$ & $\begin{array}{l}\text { H2: The competitive } \\
\text { strategy of delivery } \\
\text { performance positively } \\
\text { influences the SCM } \\
\text { with SLA }\end{array}$ & $\begin{array}{c}\text { (Rosenzweig \& Roth, } \\
\text { 2004; Slack et al., } \\
\text { 2010; Wang et al., } \\
\text { 2016) }\end{array}$ \\
\hline $\begin{array}{l}\text { QL1) The importance to seek suppliers who } \\
\text { focus on order compliance, product or service } \\
\text { quality. } \\
\text { QL2) The importance to seek suppliers who } \\
\text { are committed to order assistance, according to } \\
\text { client's negotiation. } \\
\text { QL3) The importance to seek suppliers who } \\
\text { react to changes quickly. } \\
\text { QL4) The importance to seek suppliers who } \\
\text { provide qualified technical support. } \\
\text { QL5) The importance to seek suppliers who } \\
\text { are concerned about obtaining efficient quality } \\
\text { systems. }\end{array}$ & Quality & $\begin{array}{l}\text { H3: The competitive } \\
\text { strategy of quality } \\
\text { positively influences } \\
\text { the SCM with SLA }\end{array}$ & $\begin{array}{l}\text { (Pereira-Moliner et } \\
\text { al., 2012; Pinto et al., } \\
\text { 2015; Slack et al., } \\
\text { 2010) }\end{array}$ \\
\hline
\end{tabular}




\begin{tabular}{|c|c|c|c|}
\hline $\begin{array}{l}\text { Variables analysed } \\
\end{array}$ & Constructs & Hypotheses & Authors \\
\hline $\begin{array}{l}\text { FLX1) The importance to seek flexible } \\
\text { suppliers to adapt to their products or to the } \\
\text { demand requested by the client. } \\
\text { FLX2) The importance to seek dynamic } \\
\text { suppliers when it comes to production } \\
\text { programming alteration and volume alteration. } \\
\text { FLX3) The importance to seek suppliers who } \\
\text { are ready to serve with flexibility upon } \\
\text { potential delivery date changes. } \\
\text { FLX4) The importance to seek suppliers who } \\
\text { are ready for sudden adaptations. }\end{array}$ & Flexibility & $\begin{array}{l}\text { H4: The competitive } \\
\text { strategy of flexibility } \\
\text { positively influences } \\
\text { the SCM with SLA }\end{array}$ & $\begin{array}{l}\text { (Boyer } \text { et al., 2005; } \\
\text { Lau Antonio et al., } \\
\text { 2007; Neto et al., } \\
\text { 2003; Rosenzweig \& } \\
\text { Roth, 2004) }\end{array}$ \\
\hline
\end{tabular}

INV1) The importance to seek innovative suppliers.

INV2) The importance to seek suppliers who have innovative technologies.

INV3) The importance to seek suppliers who are concerned about investing in new Innovation

H5: The competitive strategy of innovation positively influences (Sellitto et al., 2018, 2015; Teece, 2010) technologies.

INV4) The importance to seek suppliers who the SCM with SLA guarantee product supply in compliance with current technologies (Core Business).

SLA1) The importance to seek suppliers who are concerned about meet all the obligations agreed on.

SLA2) The importance to seek suppliers who previously define rights and duties between parties.

SLA3) The importance to seek suppliers who have the performance measurement of their services as a strategy along with their clients.

SLA4) The importance to seek suppliers who are flexible about the con-compliance of a given duty, and who are receptive to the application of potential penalties.

SCM1) The importance to seek suppliers who search for operational efficiency.

SCM2) The importance to seek suppliers who are positive links in all the supply chain by making logistic partnerships that are committed to delivery times.

SCM3) The importance to seek suppliers who are aligned and interconnected to their processes.

SCM4) The importance to seek suppliers who

Service

Level

Agreement
(Abbasi et al., 2018;

Chen \& Thomas,

2017; Ludwig et al., 2002) keep their stocks compatible with their demands.

SCM5) The importance to seek suppliers who have an efficient PPC - Production Planning and Control.

Source: The authors.

Figure 1 presents a model that was initially suggested with each construct separately: costs, delivery performance, quality, flexibility, innovation, and service level agreement, with all pointing to (impacting) 
the construct called SCM \& SLA. The model that was initially suggested came from the theoretical foundation, which addressed the main theories related to this research's main theme.

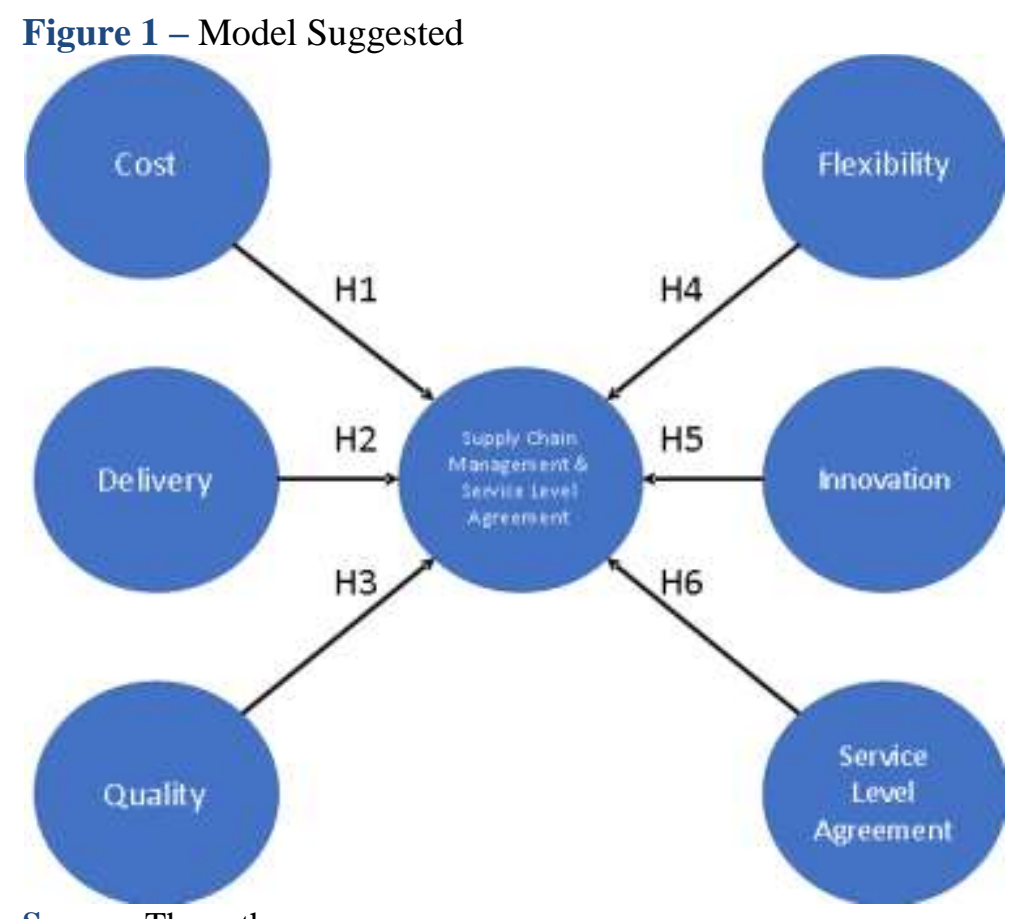

Source: The authors.

For this modelling, the Smart PLS 3.0 software was used. It was chosen due to its characteristics, a technique that is suitable for the investigation and modelling objective (Gudergan et al., 2008; Peng \& Lai, 2012). The constructs determined above were analysed as independent variables and achieved a variable defined as dependent as the final index, with the objective to summarise the set of constructs established.

\section{Results and discussion}

Based on the results obtained through the questionnaire, an analysis in the IBM SPSS ${ }^{(\mathrm{R})}$ software was performed with the objective to check the sampling adequacy. This adequacy is indicated by the KaiserMeyer-Olkin (KMO) measure (Williams et al., 2010). This value may vary between zero and one. In order for the sampling to be adequate, this value must be above 0,50 (Hair Jr. et al., 2010). The result of the KMO measure test was 0,904 , showing that the sampling data are adequate. Another way to check whether the data are adequate is through the Bartlett's sphericity test, which must present a result of significance below 0,05 . For the research data, the significance result was zero, which shows that each variable perfectly correlates to itself (Malhotra, 2008).

After checking the data adequacy, a factorial analysis was performed with the objective to group up the variables that share similar behaviours by decreasing a number of latent variables through the 
correlation between them. For the factor analysis, matrix rotation methods are used with the objective to simplify the lines and the factorial matrix rows (Hassan \& Abdel-Aty, 2011). The regrouping of the constructs is shown in Table 4, which highlights the constructs grouped up for each value.

Table 4 - Exploratory factor analysis by 4 factors

\begin{tabular}{|c|c|c|c|c|}
\hline \multicolumn{5}{|c|}{ Rotary component matrix } \\
\hline \multicolumn{5}{|c|}{ Components } \\
\hline & 1 & 2 & 3 & 4 \\
\hline CT1 & 0,338 & 0,499 & 0,086 & 0,374 \\
\hline CT2 & 0,019 & 0,231 & 0,185 & 0,822 \\
\hline CT3 & 0,227 & 0,165 & 0,392 & 0,717 \\
\hline CT4 & 0,166 & 0,189 & 0,195 & 0,815 \\
\hline CT5 & 0,176 & 0,028 & 0,488 & 0,376 \\
\hline DE1 & 0,724 & 0,265 & 0,226 & 0,17 \\
\hline DE2 & 0,544 & 0,478 & 0,011 & 0,239 \\
\hline DE3 & 0,727 & 0,337 & 0,16 & 0,119 \\
\hline QL1 & 0,712 & 0,374 & 0,164 & 0,218 \\
\hline QL2 & 0,782 & 0,317 & 0,003 & 0,046 \\
\hline QL3 & 0,479 & 0,603 & 0,206 & 0,08 \\
\hline QL4 & 0,443 & 0,547 & 0,388 & $-0,061$ \\
\hline QL5 & 0,542 & 0,516 & 0,369 & 0,083 \\
\hline FLX1 & 0,335 & 0,716 & 0,167 & 0,114 \\
\hline FLX2 & 0,186 & 0,744 & 0,19 & 0,293 \\
\hline FLX3 & 0,252 & 0,763 & 0,179 & 0,289 \\
\hline FLX4 & 0,203 & 0,712 & 0,402 & 0,213 \\
\hline INV1 & 0,202 & 0,434 & 0,752 & 0,083 \\
\hline INV2 & 0,204 & 0,291 & 0,803 & 0,131 \\
\hline INV3 & 0,125 & 0,265 & 0,804 & 0,27 \\
\hline INV4 & 0,185 & 0,067 & 0,741 & 0,382 \\
\hline SLA1 & 0,756 & 0,097 & 0,278 & 0,056 \\
\hline SLA2 & 0,652 & 0,077 & 0,382 & 0,262 \\
\hline SLA3 & 0,415 & 0,164 & 0,494 & 0,315 \\
\hline SLA4 & 0,183 & 0,347 & 0,354 & 0,460 \\
\hline
\end{tabular}

Source: The authors.

Based on the factor loads' identification criteria, the variables CT1, CT5, QL5, SLA3 and SLA4, highlighted in red, were discarded, since they are below the factor load of 0,55 . The variables highlighted in yellow are those which meet the factor load above 0,55 , and they are the variables observed that were used in the measurement model (Hair Jr. et al., 2010).

Tests with six factors were also performed, and, for this rotation, the variables turned out to be deeply divided. Therefore, the rotation by four factors was chosen with the objective to test the hypotheses established, since, with four factors, the variables presented a better grouping. After the factor analysis, it was necessary to reorganise the index abbreviations, which used to belong to six constructs but were grouped up into four constructs by the analysis after the factor, according to what is shown in Table 5 . 
Table 5 - New index nomenclature

\begin{tabular}{|c|c|c|}
\hline Initial Index & New index nomenclature & Final Construct \\
\hline CT2 & CUST1 & \multirow{3}{*}{$\mathrm{C}$} \\
\hline CT3 & CUST2 & \\
\hline CT4 & CUST3 & \\
\hline DE1 & EQSLA1 & \multirow{5}{*}{ EQSLA } \\
\hline DE2 & EQSLA2 & \\
\hline DE3 & EQSLA3 & \\
\hline QL1 & EQSLA4 & \\
\hline QL2 & EQSLA5 & \\
\hline QL3 & QF1 & \multirow{6}{*}{ QF } \\
\hline QL4 & QF2 & \\
\hline FLX1 & QF3 & \\
\hline FLX2 & QF4 & \\
\hline FLX3 & QF5 & \\
\hline FLX4 & QF6 & \\
\hline INV1 & IN1 & \multirow{4}{*}{ IN } \\
\hline INV2 & IN2 & \\
\hline INV3 & IN3 & \\
\hline INV4 & IN4 & \\
\hline SLA1 & EQSLA6 & \multirow{2}{*}{ EQSLA } \\
\hline SLA2 & EQSLA7 & \\
\hline
\end{tabular}

Source: The authors.

The variables were grouped up into four constructs according to Table 3. The group which had the highest number of grouped variables was the construct EQSLA (delivery performance, quality and SLA) (EQSLA1, EQSLA2, EQSLA3, EQSLA4, EQSLA5, EQSLA6 and EQSLA7), with three variables that refer to the delivery performance competitive criteria, two variables that refer to quality, and two variables that refer to SLA.

The construct C (costs) (CUST1, CUST2, CUST3) grouped up the lowest number of variables, with three variables that refer to the competitive strategy costs. The construct QF (quality) (QF1, QF2, QF3, QF4, QF5, QF6) grouped up two variables that refer to the competitive criteria quality, and four other variables that belong to the competitive criteria flexibility. The construct IN (innovation) (IN1, IN2, IN3, IN4) grouped up four variables that refer to the competitive criteria innovation.

The indexes EQSLA4 and EQSLA5, which belong to the construct quality after the factor analysis, grouped up with the construct EQSLA (delivery, quality, SLA). This grouping is justified, for these indexes are directly related to the importance in meeting order compliance in all its agreed conditions. The act of delivering the order to the client according to what was previously agreed on, meeting all the commercially and technically pre-established criteria, significantly increases the client's reliability (Slack et al., 2010).

The indexes EQSLA6 and EQSLA7, which, at first, belonged to the construct SLA and address the importance of developing suppliers who are concerned about meeting all the duties agreed on (Ludwig et al., 2002), after the factor analysis, were related to the construct EQSLA. Meeting all the conditions that were promised and keeping all the scheduled times make the hired supplier stand out before competitiveness 
by becoming a reference in the area where they operate. Quality can be understood as the conformation that encompasses the service aspects concerning the specifications requested, as well as satisfactorily serving the clients whenever they are requested (Slack et al., 2010).

The indexes QF1 and QF2, which originally belonged to the construct quality, and since they are connected to the search for suppliers who react quickly to changes and who provide qualified service (Chopra et al., 2004; Rosenzweig and Roth, 2004), after the factor analysis, were grouped up into the construct QF. This strategy is directly linked to product flexibility, which is attributed to the organisation's ease to adapt its products quickly to serve the client, as well as changes in production volumes and delivery dates (Wang et al., 2016).

The indexes CUST1, CUST2, CUST3, which belong to the construct costs, remained related and linked to the original construct. Due to the indexes' right adequacy in relation to the questionnaire applied, and after the factor analysis, construct $\mathrm{C}$ was named. In this same institution, the indexes IN1, IN2, IN3, IN4 were repeated and they belonged to the construct innovation, where they were properly correlated to their respective concept, backed up by the literature mentioned in this research and only adding the name to this construct, which was named IN.

After the variables' grouping through factor analysis, where six hypotheses were initially and separately suggested, H1, H2, H3, H4, H5 and H6, according to Figure 1, were grouped into four constructs. Therefore, H1 grouped up one single construct (costs), H2 grouped up three constructs (delivery performance, quality and SLA), H3 grouped up two other constructs (quality and flexibility), H4 grouped up one single construct called innovation, as presented in Figure 2.

Figure 2 - The model presented after the factor analysis

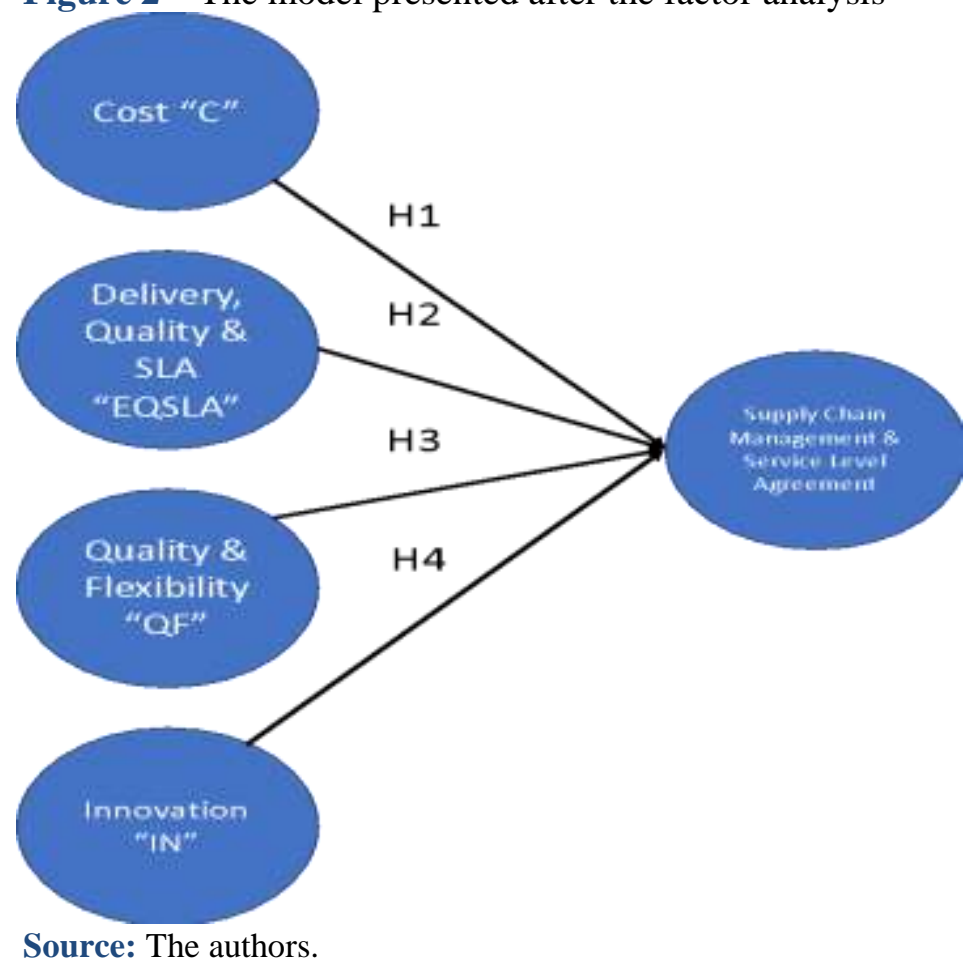


The measurement model modelling is shown in Figure 3, where the latent constructs are represented by circles, the variables observed (indexes) are represented by rectangles, and the relationship between these indexes and the constructs is represented by arrows.

$\mathrm{R}^{2}$, the construct in the blue circle (SCM with SLA), assesses the variance portion of the endogenous variables, which is explained by the structural model and shows the quality of the model adjusted (Ringle and Bido, 2014). The $\mathrm{R}^{2}$ result of the model shown in Figure 3 is 0,726 , and values above 0,6 are considered consistent (Hair Jr. et al., 2010). After the modelling with PLS, it was necessary to attest the measures which show the model's predictive capability to analyse its quality. The responses and the sample were assessed in their set through the composite reliability, which assesses the structural model's quality (Sellitto et al., 2018). Values above 0,7 are considered acceptable (Chin, 1998; Hair Jr. et al., 2010). In the model suggested, the values found for the constructs show that the composite reliability are $\mathrm{C}-$ 0,915, EQSLA - 0,924, QF - 0,924 and IN - 0,932, respectively.

Figure 3 - The model suggested in the Smart PLS 3.0 software

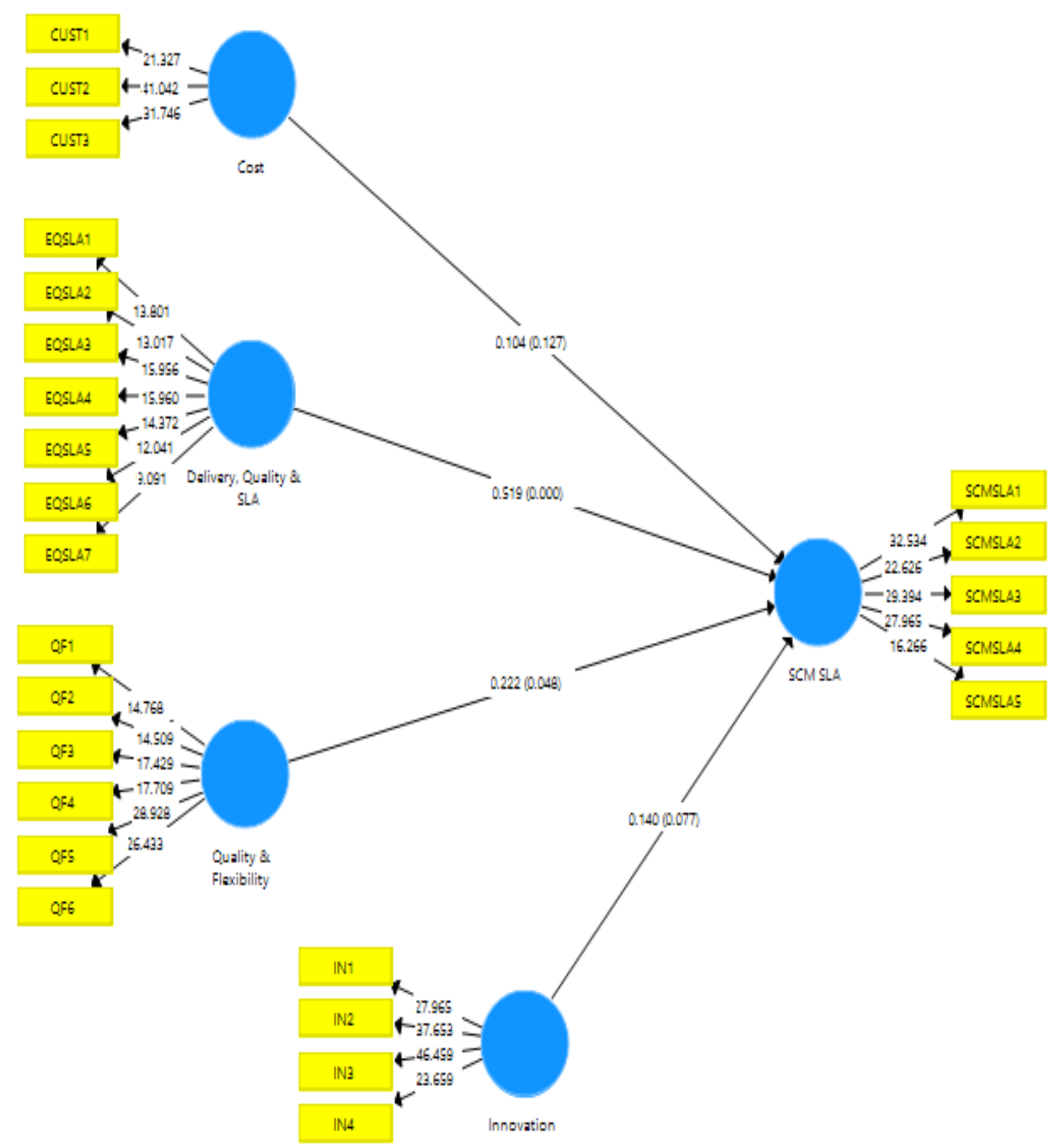

Source: The authors. 
Average Variance Extracted (AVE) is the data portion that is explained by each respective latent construct, that is, the variables that positively correlate to themselves and to their respective constructs, which is the convergent validity. AVE values higher than 0,50 mean that the model embraces the result (Fornell and Larcker, 1981). For the constructs, the respective AVEs presented C-0,781, EQSLA - 0,635, $\mathrm{QF}-0,671$ and IN - 0,773, that is, all the AVEs positively correlate to their respective constructs by admitting there are evidences that the observable variables have a convergent validity.

The Cronbach's Alpha was calculated for each construct with the following results: $\mathrm{C}-0,860$, EQSLA - 0,904, QF-0,901 and IN-0,902. The minimum value for the Cronbach's Alpha to be considered valid is 0,6 (Hair Jr. et al., 2010; Malhotra, 2008). Table 6 shows the reliability of each index with the highest values at 0,40 , according to what was stated in literature (Ringle \& Bido, 2014).

Table 6 - Index reliability

\begin{tabular}{cccc}
\hline \multirow{2}{*}{ Construct } & Index & $\begin{array}{c}\text { Index Reliability } \\
\text { External Load }\end{array}$ & Reliability \\
\hline \multirow{3}{*}{ C } & CUST1 & 0,859 & 0,7379 \\
& CUST2 & 0,900 & 0,810 \\
& CUST3 & 0,892 & 0,7957 \\
\hline \multirow{5}{*}{ EQSLA } & EQSLA1 & 0,817 & 0,667 \\
& EQSLA2 & 0,746 & 0,5565 \\
& EQSLA3 & 0,827 & 0,6839 \\
& EQSLA4 & 0,833 & 0,6939 \\
& EQSLA5 & 0,802 & 0.6432 \\
& EQSLA6 & 0,794 & 0,6304 \\
QF & EQSLA7 & 0,753 & 0,5670 \\
& QF1 & 0,781 & 0,6100 \\
& QF2 & 0,766 & 0,5868 \\
& QF3 & 0,807 & 0,6512 \\
& QF4 & 0,823 & 0,6773 \\
& QF5 & 0,873 & 0,7621 \\
IN & QF6 & 0,860 & 0,7396 \\
\hline & IN1 & 0,868 & 0,7534 \\
& IN2 & 0,901 & 0,8118 \\
& IN3 & 0,908 & 0,8245 \\
\hline SN3 & 0,838 & 0,7022 \\
\hline
\end{tabular}

Source: The authors.

The path coefficients are standardised values that fluctuate from -1 to +1 . Values closer to 1 have a more positive relationship (Sellitto et al., 2018). In order to assess the significance of the path coefficients, the t-value and significance (p-value) are used and extracted through Bootstrapping (Gudergan et al., 2008). The p-value must be between 0 and 0,05 (Sellitto et al., 2018). Table 7 shows these data. 
Table 7 - Path coefficient data

\begin{tabular}{lcc}
\hline \multicolumn{1}{c}{ Path / Hypotheses } & Coefficient size & p-values \\
\hline Cost (C) - H1 & 0,104 & 0,127 \\
Delivery, Quality and SLA(EQSLA) - H2 & 0,519 & 0,000 \\
Quality and Flexibility (QF) - H3 & 0,222 & 0,048 \\
Innovation (IN) - H4 & 0,140 & 0,077 \\
\hline
\end{tabular}

Source: The authors.

In response to hypothesis $1(\mathrm{H} 1)$, which had two questions discarded from the questionnaire after the factor analysis because they didn't present any statistical reliability, it grouped up only indexes of a single construct. Its main objective was to answer how much the competitive criterion cost positively influenced the SCM with service level agreement. It was validated for research analysis, since the construct C (costs) presented a relationship within the parameters considered adequate with SCM with SLA by presenting a load of 0,104 among the constructs. Correlation coefficients higher than 0,1 are considered meaningful, although the load among these constructs was the slowest and related to the other ones (Hair Jr et al., 2014). However, this construct's path coefficient significance didn't reach the minimum considered valid, according to what is shown in Table 7.

Hypothesis 1 (H1) is not confirmed, for its p-value was 0,127 (Table 7) in relation to the SCM with service level agreement. This result goes against the circumstances in the petrochemical industry, for the way this industry obtains gains is through the rationalisation of the maintenance activities, which is the second highest purchasing cost, only behind crude oil.

Maintenance in this kind of business is predominantly done by third-party suppliers, and this activity impacts on the interruption of the production unit and causes great financial losses to the companies. Thus the aspect cost is not as important in this segment (Ritson et al., 2017). The maintenance of the efficient processes optimises its resources and adds value to its product or service, thus increasing the service level every client expects from their supplier (Chen and Thomas, 2017).

After the factor analysis, hypothesis $2(\mathrm{H} 2)$ grouped up indexes from three constructs, which are: delivery performance, flexibility and service level agreement, which produced a new construct, called EQSLA, that was validated for the research sample with the highest parameter and presented a load of 0,519 among the constructs. The higher the correlation coefficients, the more powerful the sign of a link among them (Hair Jr et al., 2014). Hypothesis 2 (H2) has its constructs directly interconnected in the SCM. Meeting the scheduled time and correcting any fault immediately after they happen will being delivery reliability, just as supplying products or delivering services according to the client's expectations instantly reflect on its performance index, since the greatest measurers for such assessment are the items grouped up in this construct (Porter, 2008). The performance measurement of a given supplier is defined from their clients' needs and preferences (Slack et al., 2010). It is important to point out the importance of explaining all the suppliers' duties so that a previous analysis of service capability to what is being requested is possible (Wang \& Wu, 2016). In all its indexes, hypothesis 2 (H2) has the key processes within the supply chain, 
which are significantly analysed and measured from the suppliers' assessment. The continuous improvement is present in every organisation as a business strategy. Therefore, meeting all the conditions determined and not negatively impacting on any client's step will turn them into a business partner, thus increasing the performance measurement criteria (Ballou, 2007).

In response to hypothesis $3(\mathrm{H} 3)$, and after its factor analysis, indexes from two distinct constructs were grouped up, which are quality and flexibility, with the objective to answer whether the new QF construct positively impacts the SCM with SLA as well. This construct had its research validated with the adequacy of its parameters, with a load of 0,222 among the constructs, which is found within the parameters considered acceptable for such correlation (Hair Jr. et al., 2010). Flexibility is defined as the capability to vary in the face of the new rules to be followed by allowing a positive correspondence with changes in the activities that the management processes of the supply chain need to deal with and by allowing a satisfactory performance at short notice (Neto et al., 2003). Quality is the strategy guided to the need of the client, who is ready for any adverse situation without jeopardising their service level (Pereira-Moliner et al., 2012; Pinto et al., 2015). The desirable quality must be aligned with the client's preferences by keeping product quality always aiming at fascination and its consequent loyalty (Rosenzweig \& Roth, 2004). Hypothesis 3 (H3) shows that a strategy wrongly applied may invalidate the entire process. Thus, when an organisation carries their business strategically, it takes into account threats and opportunities that are inherent to the external environment. This statement takes on a special condition, especially if they are guided into the supply chain that exists in the process that holds the interconnection of a series of internal and external steps and which oftentimes differ from each other (Slack et al., 2010). One of the important criteria in this strategy and delivery flexibility lies in quickly reacting to the changes in delivery times that were previously agreed on, whether for longer or shorter (Ritson et al., 2017). Meeting this requirement means obtaining desired service levels by positively impacting on all the supply chain (Chopra \& Meindl, 2016).

After the factor analysis for hypothesis 4 (H4), it grouped up indexes of a single construct which aimed at answering how much the innovation competitive criterion positively influenced the SCM with service level agreement. The research sample was validated by obtaining a load of 0,140 of correlation between the constructs innovation (IN) and the construct SCM and SLA. However, this path had no significance and, so, this construct has no positive impact on the dependent variable (p-value: 0,077), according to what is shown in Figure 3. The petrochemical industry is based on continuous industrial processes. In continuous processes, the assets' maintenance is a key-factor for the business. This business' economic indexes reflect the impacts caused by a possible disruption (lack of materials) and process failures. This industry has no innovative character concerning its processes and operations, but it does when it comes to its products and services, enabling this criterion to not impact on the operations' strategy (Eidelwein et al., 2016). Therefore, innovative strategies are suggested in the petrochemical industry concerning its processes and operations (Ritson et al., 2017). 


\section{Conclusion}

The search for higher service levels is a necessity for organizations. The choice of suppliers is essential to maintain a well-developed and structured production chain. From a defined supply chain, it is possible to imagine that you will be able to deliver value to your links, especially the customer. Customers are sensitive to the service they receive from suppliers. Better levels mean more value and, consequently, a higher financial return for organizations. Service level agreements assist in this regard, as they assist in delineating the expected performance, with determined requirements and penalties.

An environment that requires such an agreement is important for the petrochemical sector, given its complexity of operation. In this sense, the present study investigated what would be the criteria for establishing service level agreements, from the perspective of professionals in the area of supplies in the petrochemical sector. The suggested model identified which variables had a positive effect within the supply chain and SLA. For such, the competitive criteria were used supported by literature as a restrictor of this measurement. They were worked out under the form of constructs, with the objective to correlate information and measure its relationship with other constructs. Thus, the unification of one or more criteria is justified and this creates a new construct, which will serve as a determining factor for the preparation of service levels. It should be mentioned that the competitive criteria that are conceptualised by literature in this study keep their original concept, and their grouping only happens due to their inter-relations, which aims at the suggested modelling.

With regard to contributions of this work, some situations can be highlighted. First, the research brings contributions to the supply chain management literature. The research effort of this article in presenting a connection model between the constructs worked on, advances in the discussion of such elements for a more developed and structured supply chain management within the petrochemical sector. With this, it is possible to perceive the second great contribution of the research, this one from the point of view for managerial practice. Upon considering the reality of the Southern Petrochemical Centre, it is possible to understand the relevance of this research's findings as guides in the improvement process within the product generation chain. The Southern Petrochemical Centre has a productive capability of 1,4 million tons/year and is a $1^{\text {st }}, 2^{\text {nd }}, 3^{\text {rd }}$ and $4^{\text {th }}$ generation producer. The latter generation involves the segment of recycled materials (Abiquim, 2018). Due to its representativeness by integrating three centres of innovation that stand out in Latin America, the elaboration of the service levels according to competitive criteria becomes important for the management process and the competitiveness strategy in the search for suppliers who are aligned to the needs, besides the criteria that must be analysed during the establishment of a new partner.

Several research limitations can be associated to the number of respondents. Although the return rate was above the expected $(35,61 \%)$ and within the parameters expected, according to literature, a higher number of responses would result in a higher consistency to the model suggested. This investigation's model was based on 104 interviewees and, therefore, it should not consider a final model nor a finished 
model as well. Thus, for future researches, here is the suggestion to expand the research with a larger sample of national and international representativeness from the petrochemical sector, assess the suggestion of preparation of a model by measuring the main difficulties and frailties the suppliers have upon meeting their service levels that are desired and specified by their clients and, thus, be able to see if what is being requested is manageable and determine if what is being measured is either practicable or not for the chosen partners in this important sector.

\section{References}

Abbasi, B., Hosseinifard, Z., Alamri, O., Thomas, D. \& Minas, J.P. (2018). Finite time horizon fill rate analysis for multiple customer cases. Omega (United Kingdom) 76, 1-17. doi:10.1016/j.omega.2017.03.004.

Abiquim. (2018). Associação Brasileira de Indústria Química. O Desempenho da Indústria Química Brasileira em 2018. Avaiable at: www.abiquim.org.br. Accessed: dec 14, 2018.

Ballou, R.H. (2007). Business logistics/supply chain management: planning, organizing, and controlling the supply chain. Pearson Education India, 2007. Pearson Education, India.

BCIA, (2018). The performance of the Brazilian Chemical Industry. Brazilian Chemical Industry Association, Sao Paulo.

Bogataj, D., Bostjan, A. \& Bogataj, M. (2016). Supply chain risk at simultaneous robust perturbations. Int. J. Prod. Econ. 181, 68-78.

Bowersox, D.J., Closs, D.J. \& Cooper, M.B. (2002). Supply chain logistics management, McGraw-Hill.

Boyer, K.K. (1998). Longitudinal linkages between intended and realized operations strategies. Int. J. Oper. Prod. Manag. 18, 356-373. doi:10.1108/01443579810199739.

Boyer, K.K., Swink, M. \& Rosenzweig, E.D. (2005). Describing the POMS Operations. Prod. Oper. Manag. 14, 442-449. doi:10.1111/j.1937-5956.2005.tb00232.x.

Chen, C.-M.J. \& Thomas, D.J. (2017). Inventory Allocation in the Presence of Service Level Agreements. Prod. Oper. Manag. 12, 3218-3221. doi:10.1111/poms.12814.

Chin, W.W. (1998). The partial least squares approach to structural equation modeling. In G.A. Marcoulides (ed.) Modern methods for business research. Mahwah, New Jersey Lawrence Erlbaum Assoc. 295-336.

Chopra, S., Lovejoy, W. \&Yano, C. (2004). Five Decades of Operations Management and the Prospects Ahead. Manage. Sci. 50, 8-14. doi:10.1287/mnsc.50.1.8.27056.

Chopra, S. \& Meindl, P. (2016). Supply Chain Management: Strategy, Planning, and Operation, Supply Chain Management: Strategy, Planning, and Operation. Tsinghua University Press.

Eidelwein, F., Hoffmann, M., Piran, F., Neves, C. \& Nunes, F. (2016). Systemic evaluation of maintenance management model in a brazilian petrochemical company. Espacios 37. 
Eltantawy, R., Paulraj, A., Giunipero, L., Naslund, D. \& Thute, A.A. (2015). Towards supply chain coordination and productivity in a three echelon supply chain: Action research study. Int. J. Oper. Prod. Manag. 35, 895-925.

Fornell, C. \& Larcker, D.F. (1981). Evaluating Structural Equation Models with Unobservable Variables and Measurement Error. J. Mark. Res. 18, 39-50.

Forza, C. (2002). Survey research in operations management: a process-based perspective. Int. J. Oper. Prod. Manag. 22, 152-194. doi:10.1108/01443570210414310.

Gudergan, S.P., Ringle, C.M., Wende, S. \& Will, A. (2008). Confirmatory tetrad analysis in PLS path modeling. J. Bus. Res. 61, 1238-1249. doi:10.1016/j.jbusres.2008.01.012.

Hair Jr., J.F., Black, W.C., Babin, B.J., Anderson, R.E. \& Tathan, R.L. (2010). Multivariate Data Analysis. New York - NY.

Hair Jr, J.F., Hult, G.T.M., Ringle, C. \& Sarstedt, M. (2016). A primer on partial least squares structural equation modeling (PLS-SEM). Sage Publications.

Hair Jr, J.F., M., S., Hopkins, L. \& Kuppelwieser, V.G. (2014). Partial least squares structural equation modeling (PLS-SEM) An emerging tool in business researchitle. Eur. Bus. Rev. 26, 106-121.

Hassan, H.M. \& Abdel-Aty, M.A. (2011). Analysis of drivers' behavior under reduced visibility conditions using a Structural Equation Modeling approach. Transp. Res. Part F Traffic Psychol. Behav. 14, 614-625. doi:10.1016/j.trf.2011.07.002.

Junior, J.B.C, Vitorino Filho, V.A., Pires, S.L.I, Sacomano Neto, M. (2014). Coopetição como estratégia de auxílio na gestão de riscos em cadeias de suprimentos. Revista Ibero-Americana de Estratégia, 13 (2), 39-52. doi: 10.5585/riae.v13i2.2030.

Krummenauer, R. \& Nunes, F. (2017). Proposta de melhorias na manutenção autônoma do setor de utilidades de uma planta petroquímica. Produção em Foco 7, 338-359. doi:10.14521/p22375163.2017.0012.0008.

Lambert, D.M., Cooper, M.C.\& Pagh, J.D. (1998). Supply chain management: implementation issues and research opportunities. Int. J. Logist. Manag. 9, 1-20. doi:10.1108/MRR-09-2015-0216.

Lau Antonio, K.W., Yam, R.C.M. \& Tang, E. (2007). The impacts of product modularity on competitive capabilities and performance: An empirical study. Int. J. Prod. Econ. 105, 1-20. doi:10.1016/j.ijpe.2006.02.002.

Ludwig, H., Keller, A., Dan, A., King, R.P. \& Franck, R. (2002). Web Service Level Agreement (WSLA) Language Specification. IBM Corp. 1-110. doi:10.1109/WECWIS.2002.1021238.

Malhotra, N.K. (2008). Marketing research: An applied orientation. Pearson Education: India.

Menor, L.J., Roth, A. V. \& Mason, C.H. (2001). Agility in Retail Banking: A Numerical Taxonomy of Strategic Service Groups. Manuf. Serv. Oper. Manag. 3, 273-292. doi:10.1287/msom.3.4.273.9969.

Muller, C., Fernandez, P., Diaz, O.M., Gutierrez, A.M., Resinas, M. \& Cortes, A.R. (2017). Specifying Compensations with WS-Agreement. IEEE Lat. Am. Trans. 15, 1335-1341.

doi:10.1109/TLA.2017.7959515. 
Neto, J.P.B., Fensterseifer, J.E. \& Formoso, C.T. (2003). Os Critérios Competitivos da Produção : um Estudo Exploratório na Construção de Edificações. RAC - Rev. Adm. Contemp. 7, 67-85. doi:10.1590/S1415-65552003000100004.

Owoloko, E.A., Iaeng, M. \& Ezekiel, I.D. (2017). Determining the Optimal Policies for Product Supply Chain Management System II, 3-7.

Peng, D.X. \& Lai, F. (2012). Using partial least squares in operations management research: A practical guideline and summary of past research. J. Oper. Manag. 30, 467-480. doi:10.1016/j.jom.2012.06.002.

Pereira-Moliner, J., Claver-Corts, E., Molina-Azorn, J.F. \& Tar, J.J. (2012). Quality management, environmental management and firm performance: Direct and mediating effects in the hotel industry. $J$. Clean. Prod. 37, 82-92. doi:10.1016/j.jclepro.2012.06.010.

Pinto, J.R.C., Nunes, F.L. \& Viero, C.F. (2015). Productivity gains and cost savings generated by the assessment process automation in a footwear company: A case study. Espacios 36.

Porter, M.E., (2008). On competition. Harvard Business Press.

Ringle, C.. da S. \& Bido, D. D. (2014). Modelagem de equações estruturais com utilização do SmartPLS. Rev. Bras. Mark. 13, 56-73.

Ritson, N.H., Wilson, M.M.J. \& Cohen, D.A. (2017). Managing engineering contractors in the UK petrochemicals industry. Eng. Constr. Archit. Manag. 24, 1067-1080. doi:10.1108/ECAM-08-20150127

Rosenzweig, E. \& Roth, A. (2004). Towards a theory of Competitive Progression: Evidence from HighTech Manufacturing. Prod. Oper. 13, 354-368. doi:10.1111/j.1937-5956.2004.tb00223.x.

Sellitto, M.A., Nunes, F.L. \& Vallladares, D.R.F. (2018). Factors That Contribute To the Use of Modularisation in the Automotive Industry: a Survey in Brazil. South African J. Ind. Eng. 29, 33-44. doi:10.7166/29-4-1946.

Sellitto, M.A., Pereira, G.M., Borchardt, M., Da Silva, R.I. \& Viegas, C.V. (2015). A SCOR-based model for supply chain performance measurement: Application in the footwear industry. Int. J. Prod. Res. 53, 4917-4926. doi:10.1080/00207543.2015.1005251.

Sheehan, K.B. (2006). E-mail Survey Response Rates: A Review. J. Comput. Commun. 6. doi:10.1111/j.1083-6101.2001.tb00117.x.

Singh, G., Tripathi, A., Srivastava, A. \& Iyer, M. (2015). Integrated supply Chain outsourcing Expanding the role of third party logistics in the upstream industry. Soc. Pet. Eng. - SPE Oil Gas India Conf. Exhib.

Slack, N., Chambers, S. \& Johnston, R. (2010). Operations management. Pearson Education Limited.

Teece, D.J. (2010). Business models, business strategy and innovation. Long Range Plann. 43, 172-194. doi:10.1016/j.lrp.2009.07.003

Teixeira, R., Lacerda, D.P., Antunes, J. \& Veit, D. (2014). Estratégia de Produção: 20 artigos clássicos para aumentar a competitividade da empresa. Bookman, Porto Alegre. 
Vitorino Filho, V.A., Moori, R.G. (2018). O efeito moderador das capabilidades da manufatura na relação entre gestão estratégica da cadeia de suprimentos e desempenho de negócios. Revista Ibero-Americana de Estratégia, 17 (4), 71-89. doi: 10.5585/ ijsm.v17i4.2634.

Volk, E., Müller, M., Jacob, A., Racz, P. \& Waldburger, M. (2009). Increasing capacity exploitation in food supply chains using grid concepts. Lect. Notes Comput. Sci. (including Subser. Lect. Notes Artif. Intell. Lect. Notes Bioinformatics 5745 LNCS, 88-101. doi:10.1007/978-3-642-03864-8_7.

Voorhees, C.M., Brady, M.K., Calantone, R. \& Ramirez, E. (2016). Discriminant validity testing in marketing: an analysis, causes for concern, and proposed remedies. J. Acad. Mark. Sci. 44, 119-134. doi:10.1007/s11747-015-0455-4.

Wang, J. \& Wu, L. (2016). The impact of emotions on the intention of sustainable consumption choices : evidence from a big city in an emerging country. J. Clean. Prod. 126, 325-336. doi:10.1016/j.jclepro.2016.03.119.

Wang, Z., Zhang, M., Sun, H. \& Zhu, G. (2016). Effects of standardization and innovation on mass customization: An empirical investigation. Technovation 48-49, 79-86. doi:10.1016/j.technovation.2016.01.003.

Wheeldon, J. \& Faubert, J. (2009). Framing experience: concept maps, mind maps and data collection in qualitative research. Int. J. Qual. Methods 68-83.

Williams, B., Onsman, A. \& Brown, T. (2010). Exploratory factor analysis: A fivestep guide for novices. Journal of Emergency Primary Health Care (JEPHC), 8 (3), 2010.

Wong, K.K. (2013). Partial Least Squares Structural Equation Modeling (PLS-SEM) Techniques Using SmartPLS. Mark. Bull. 32.

Zammori, F., Braglia, M. \& Frosolini, M. (2009). A standard agreement for vendor managed inventory. Strateg. Outsourcing An Int. J. 2, 165-186. doi:10.1108/17538290910973376. 